\title{
Extensive soft-sediment deformation and peperite formation at the base of a rhyolite lava: Owyhee Mountains, SW Idaho, USA
}

\author{
Charlotte E. McLean $^{1}$ • David J. Brown ${ }^{1} \cdot$ Heather J. Rawcliffe ${ }^{1}$
}

Received: 26 October 2015 / Accepted: 21 April 2016

(C) The Author(s) 2016. This article is published with open access at Springerlink.com

\begin{abstract}
In the Northern Owyhee Mountains (SW Idaho), a $>200$-m-thick flow of the Miocene Jump Creek Rhyolite was erupted on to a sequence of tuffs, lapilli tuffs, breccias and lacustrine siltstones of the Sucker Creek Formation. The rhyolite lava flowed over steep palaeotopography, resulting in the forceful emplacement of lava into poorly consolidated sediments. The lava invaded this sequence, liquefying and mobilising the sediment, propagating sediment subvertically in large metre-scale fluidal diapirs and sediment injectites. The heat and the overlying pressure of the thick Jump Creek Rhyolite extensively liquefied and mobilised the sediment resulting in the homogenization of the Sucker Creek Formation units, and the formation of metre-scale loading structures (simple and pendulous load casts, detached pseudonodules). Density contrasts between the semi-molten rhyolite and liquefied sediment produced highly fluidal Rayleigh-Taylor structures. Local fluidisation formed peperite at the margins of the lava and elutriation structures in the disrupted sediment. The result is a $30-40-\mathrm{m}$ zone beneath the rhyolite lava of extremely deformed stratigraphy. Brittle failure and folding is recorded in more consolidated sediments, indicating a differential response to loading due to the consolidation state of the sediments. The lava-sediment interaction is interpreted as being a function of (1) the poorly consolidated nature of the sediments, (2) the thickness and heat retention of the rhyolite lava, (3) the density contrast between the lava and the sediment and (4) the forceful
\end{abstract}

Editorial responsibility: P-S Ross

Charlotte E. McLean

c.mclean.1@research.gla.ac.uk

1 School of Geographical and Earth Sciences, University of Glasgow, Gregory Building, Lilybank Gardens, Glasgow G12 8QQ, UK emplacement of the lava. This study demonstrates how large lava bodies have the potential to extensively disrupt sediments and form significant lateral and vertical discontinuities that complicate volcanic facies architecture.

Keywords Peperite $\cdot$ Rhyolite $\cdot$ Soft-sediment deformation · Fluidisation

\section{Introduction}

Rhyolite magmas typically extrude comparatively smallvolume lava domes of high viscosity, yet some rhyolitic volcanic fields produce voluminous lava flows, often hundreds of metres thick (Bonnichsen 1982; Henry et al. 1990; Bonnichsen and Kauffman 1987; Branney et al. 2008). Large volume silicic volcanism producing extensive, high temperature silicic lava flows and lava-like ignimbrites is characterised as "SR-type", or "Snake River-type" volcanism by Branney et al. (2008) and is typical of the bimodal Columbia River-Yellowstone Volcanic Province in the NW of the USA. Thick rhyolite lava flows $(>50 \mathrm{~m})$ can impose huge amounts of downward force and heat on to the underlying substrate. When this substrate is soft, unconsolidated sediment, the effects of loading and heat can significantly modify the local stratigraphic architecture, either by local compaction and induration (Christiansen and Lipman 1966; Henry et al. 1990) or sediment fluidisation and peperite formation (Kokelaar 1982). Exposure of the contact between rhyolite lava flows and underlying sediment is rare, notably because rhyolite lava domes tend to form as opposed to lava flows (Branney et al. 2008) and can be poorly exposed either due to insufficient erosion or talus cover (Dadd 1992; Manley 1996). A road-cut exposure on Route 95 (N $43^{\circ} 24^{\prime} 26.1^{\prime \prime}$, W $\left.116^{\circ} 51^{\prime} 54.4^{\prime \prime}\right)$ through the Jump Creek Rhyolite (JCR), a 
SR-type rhyolite lava flow, in the Owyhee Mountains, SW Idaho, provides a valuable opportunity to study the contact between a voluminous rhyolite lava flow and the underlying sediments, allowing for the construction of a detailed 2-D cross-section through the lava pile and the volcaniclastic sediment substrate, the Sucker Creek Formation (SCF) (Bonnichsen et al. 2004; Bonnichsen and Godchaux 2006).

The majority of research recording disruption along a rhyolite-sediment contact documents the remobilisation of sediments and peperite formation surrounding rhyolitic intrusive bodies (e.g. Hanson and Schweickert 1982; Kokelaar 1982; Hanson and Wilson 1993; Hanson and Hargrove 1999; Dadd and Van Wagoner 2002; Donaire et al. 2002; Skilling et al. 2002; Németh et al. 2008). In contrast, there have been very few studies on peperite formation and sediment fluidisation at the base of a rhyolite lava flow (Henry et al. 1990; Tuffen et al. 2001; Branney et al. 2008), where the sediment substrate is often less confined and where surface topography and environmental setting (e.g. water-logged sediments) are important factors (Skilling et al. 2002). Determining the processes that occur at the base of rhyolite lavas is important for a number of reasons, including the interpretation of volcanic successions in difficult ancient terranes where textures can often be obscured, and understanding the flow mechanics of large volume lava flows over soft substrates.

This paper presents a field-based textural analysis of the complex and extensive deformation along a rhyolite lavasediment contact and identifies and discusses the formation of metre-scale structures formed in fluid-saturated sediments beneath thick lava flows (>50 m), including: (1) brittle failures and folding, (2) soft-sediment deformation structures (diapirs and elutriation), (3) reverse-density structures (load casts, pseudonodules) and (4) peperite. The origin of widespread deformation beneath the JCR is addressed by considering the consolidation and water saturation of the sediments, the volume of loading, the rate of cooling of the lava flow, the density contrast between the rhyolite and sediments and the palaeotopography at time of lava emplacement. We propose that due to the thickness and heat retention of rhyolite flows, the likelihood of prolonged fluidisation and liquefaction increases, allowing deformation structures to be up to ten times larger than the submetre-scale deformation commonly identified in basalt systems (Needham 1978; Hall and Els 2002; Waichel et al. 2007).

\section{Nomenclature and terminology}

Soft-sediment deformation structures occur in completely or partially unconsolidated, fluid-saturated sediments and form when sediments are remobilised by any of several driving mechanisms: liquefaction, fluidisation, reverse-density gradients and shear stress (Mills 1983; Jones and Omoto 2000).
The remobilisation of sediment is initiated by several different "triggers", including: (1) rapid sediment loading, (2) seismic activity, (3) slope failure, (4) heat and (5) oscillation of water waves and groundwater currents (Owen et al. 2011). The loading of a lava on to unconsolidated sediments is also considered a trigger for soft-sediment deformation (e.g. Owen 1996; Jones and Omoto 2000; Hall and Els 2002). The remobilisation of sediments is primarily driven by liquefaction and/or fluidisation and is dependent on pore fluid pressure (Maltman and Bolton 2003; Owen et al. 2011). The increase in pore fluid pressure can occur by both internal and external means, either by the application of a load with which pore fluid drainage is unable to keep pace and remain at constant hydrostatic pressure or by pore fluid vaporisation and expansion (Mills 1983).

Both liquefaction and fluidisation can be defined as the rapid breakdown of the grain supported structure of unconsolidated or partially consolidated sediments (Mills 1983). Here, we define liquefaction as having occurred when sediment is supported solely by pore fluid and there is little or no cohesion between grains and thus, no strength (Allen 1982; Owen 1996, 2003; Owen et al. 2011). The sediment unit can then deform as a fluid (Maltman and Bolton 2003). Deformation by liquefaction occurs homogeneously throughout the sediment unit or units. Fluidisation is defined as the transmitting of fluids through sediment causing the particles to become supported and entrained within the fluid (Allen 1982; Owen 1996; Skilling et al. 2002; Owen et al. 2011). The shear stress of the upward directed fluid matches the weight of the grains (Owen et al. 2011). Fluidisation typically occurs locally within a unit, with fluid movement controlled by vertical conduits (e.g. fluid escape structures and clastic dykes) (Owen et al. 2011). When mobilised, the sediment will become entrained in this upward moving current, forming sediment diapirs and elutriation structures.

\section{Geological overview}

\section{Geological history and setting}

The JCR, the focus of this study, sits at the intersection of the Oregon-Idaho Graben (OIG) and the Western Snake River Plain (WSRP) (Fig. 1a, b). The OIG is a Miocene-age, N-Strending, extensional graben situated in southwestern Idaho and southeastern Oregon at the most northerly extent of the Basin and Range Province (Pierce and Morgan 1992; Manley 1995; Cummings et al. 2000; Wood and Clemens 2002) (Fig. 1a). The WSRP, an extensional graben associated with the bimodal Colombia River-Yellowstone Volcanic Province, partially cuts the north of the OIG (Wood and Clemens 2002) (Fig. 1a). Lake Bruneau, a lake equivalent to the size of the present day Great Lakes of North America, filled the OIG 


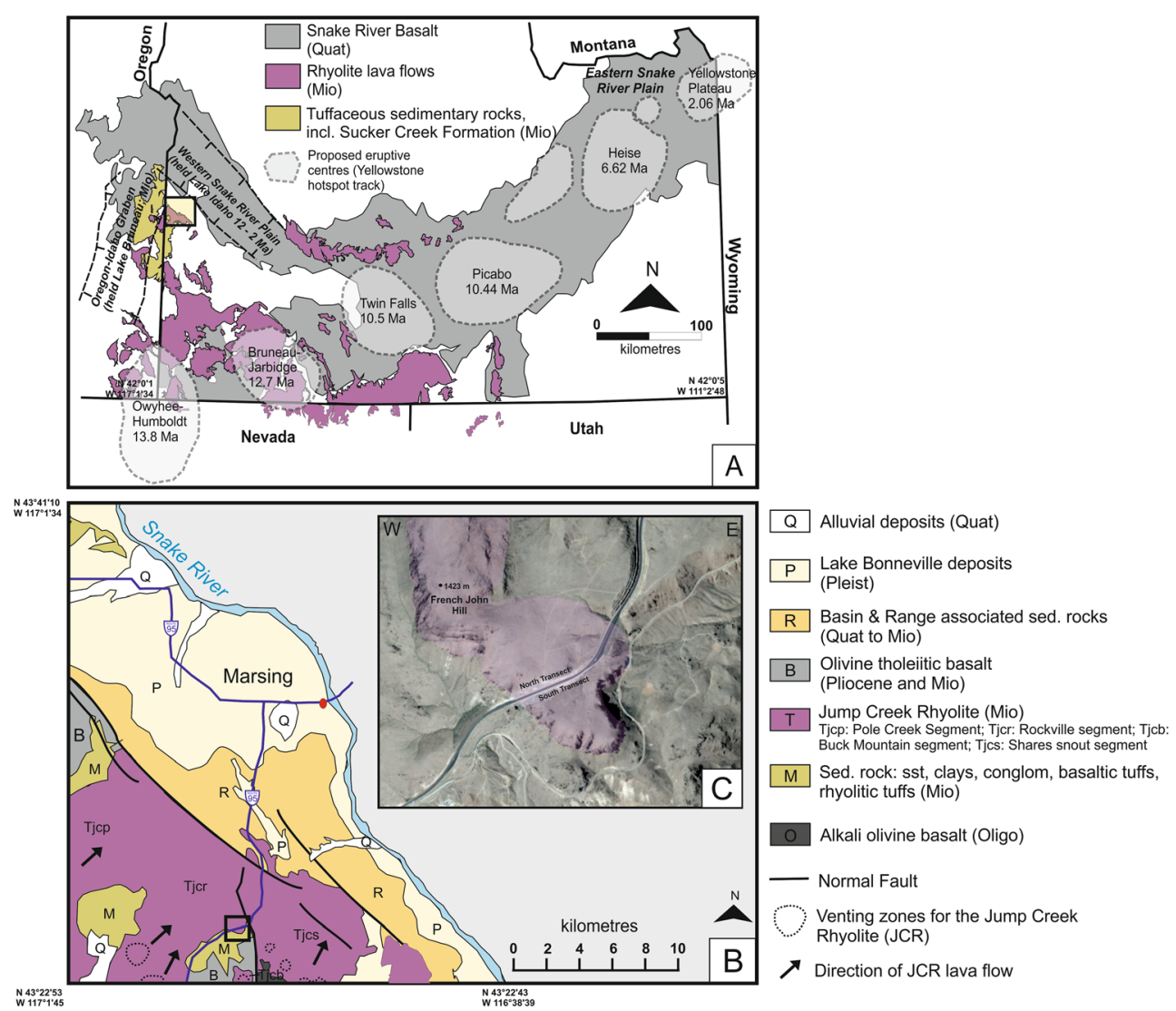

Fig. 1 Location map of the study area. a Map primarily of S. Idaho and SE. Oregon, showing the distribution of Miocene rhyolite lava flows and the Sucker Creek Formation. Note arcuate geometry of the Snake River Plain shown in grey. Proposed eruptive centres of the Yellowstone hotspot track highlighted and dates of initial volcanism specified. Figure adapted from Walker and MacLeod (1991), Pierce and Morgan (1992), Cummings et al. (2000) and Lewis et al. (2012). Owyhee Mountains highlighted by box. b Geological map of field area, south of the Snake
River (Bonnichsen and Godchaux 2006). "Owyhee Front" rhyolite venting zones highlighted by dotted areas, and direction of lava flows indicated (Bonnichsen et al. 2004). The Jump Creek Rhyolite JCR is differentiated into segments. Study locality boxed. c Aerial photograph of French John Hill and the road-cut locality, showing the position of the north and south transects illustrated in Fig. 2. The JCR lava lobe is highlighted in purple during the Mid-Late Miocene (Warner 1977). Thick accumulations of sediment (estimates between 500 and $2000 \mathrm{~m}$ ) were deposited into Lake Bruneau, are now recognised as the Mascall Formation, the Sucker Creek Formation, the Drip Spring Formation, and the Trout Creek Formation (Warner 1977; Altaner and Grim 1990; Cummings et al. 2000), and are exposed today mainly in SW Oregon (Kimmel 1982) (Fig. 1a).

The cessation of OIG development at around $11 \mathrm{Ma}$ was marked by a switching of regional tectonic stresses and the formation of the northwest-orientated WSRP (Cummings et al. 2000). The WSRP is situated $100 \mathrm{~km}$ north of the Yellowstone hotspot trail (Pierce and Morgan 1992; Shervais and Hanan 2008) (Fig. 1a). The thermal anomaly of the Yellowstone hotspot softened the lithosphere, triggering failure along planes with weak lithostatic strength and initiated rifting (Pierce and Morgan 1992; Wood and Clemens 2002; Bonnichsen et al. 2004, 2008). Rifting of the WSRP began at $\sim 12 \mathrm{Ma}$, correlating with the passage of the hotspot to the south and ceased at $\sim 7$ Ma (Pierce and Morgan 1992; Wood and Clemens 2002; Bonnichsen et al. 2004). The low topography of the WSRP was filled with Lake Idaho from its formation at 12 to $2 \mathrm{Ma}$ (Wood and Clemens 2002; Branney et al. 2008) (although it is unclear if the lake was consistently present during this time) (Bonnichsen et al. 2004). It is estimated that Lake Idaho covered an area of $20,000 \mathrm{~km}^{2}$ at its maximum (Branney et al. 2008).

Associated with the initial rifting of the WSRP, between 11.7 and 11.0 Ma, localised rhyolite lavas, the "Owyhee Front volcanism" (the Jump Creek Rhyolite lava, the Reynolds Creek Rhyolite lava, the Cerro el Otoño Dome Field and the Wilson Creek Ignimbrite) were extruded from venting zones at the margins of the WSRP (Pierce and Morgan 1992; Perkins and Nash 2002; Bonnichsen et al. 2004, 2008; Bonnichsen 
and Godchaux 2006; Fig. 1b). Large lava sheets were formed rather than rhyolite domes due to high temperatures and high effusion rates (Bonnichsen and Kauffman 1987).

\section{The Jump Creek Rhyolite lava (11.1 $\pm 0.2 \mathrm{Ma})$}

The Jump Creek Rhyolite is the most extensive of the Owyhee Front rhyolite lavas, covering an area of up to $100 \mathrm{~km}^{2}$ and is locally up to $300 \mathrm{~m}$ thick (Kittleman et al. 1965; Cummings et al. 2000; Bonnichsen et al. 2004). Isotopic dating (K/Ar) indicates an age of $11.1 \pm 0.2 \mathrm{Ma}$ (Rockville Segment, see below) (Armstrong et al. 1980), which suggests an association with the beginning of the WSRP rifting event (Bonnichsen and Godchaux 2006). Age and chemical similarities with the lavas extruded from the Bruneau-Jarbidge hotspot centre, a Late Miocene Yellowstone hotspot centre (Fig. 1a), suggests the JCR, and the other Owyhee Front rhyolites, were associated with the same magmatic and tectonic events that erupted the rhyolite magmas at the Bruneau-Jarbidge centre (Bonnichsen et al. 2004).

Bonnichsen et al. (2004) provide a detailed account of the characteristics, petrographic ages and geochemistry of the JCR, which is summarised here. The JCR can be separated into four distinctive units: the Shares Snout Segment, the Rockville Segment, the Pole Creek Top Segment and the Buck Mountain Segment, which are separated by screens of older rock formations (Bonnichsen et al. 2004). These lavas typically flowed from vents in the southwest to the northeast towards the southern margins of the WSRP (Fig. 1a). It is suggested that some of the lavas flowed over steep escarpments and/or into Lake Idaho, where magma-water interactions brecciated the lava flows (Bonnichsen et al. 2004). This study concentrates on a portion of the Rockville Segment. The Rockville Segment has a typical thickness of 50 to $200 \mathrm{~m}$, and its volume has been estimated at $5-15 \mathrm{~km}^{3}$ (Bonnichsen et al. 2004).

\section{The Sucker Creek Formation (Mid-Late Miocene)}

The Sucker Creek Formation (SCF) is a lacustrine and fluvial succession (flood plain) consisting of lignite-rich shales (hydrocarbon-bearing), clay-rich siltstones, sandstones and volcaniclastic sediments and tuffs, which were initially deposited in the lacustrine and fluvial systems associated with Lake Bruneau and later Lake Idaho in the Mid-Late Miocene (Altaner and Grim 1990; Warner 1977). The formation also contains some welded and non-welded ignimbrites and minor rhyolite flows (Walker and MacLeod 1991). Sediments were deposited by southeast to northwest flowing fluvial systems, originating from the uplifted volcanic terranes on the eastern margin of the OIG in SW Idaho (Cummings et al. 2000). The SCF has been dated using ${ }^{40} \mathrm{Ar} /{ }^{39} \mathrm{Ar}$ to $14.93 \pm 0.08 \mathrm{Ma}$, from a silicic tuff from SE Oregon (Perkins et al. 1998). Widespread sedimentation of the SCF continued into the Late Miocene and is associated with the last stage of evolution of the OIG, dated to 12.6-10.5 Ma (Cummings et al. 2000). The development of Lake Idaho around this time (12 Ma), suggests the SCF was likely to have been deposited into the drainage system of Lake Idaho in the latter stages of SCF deposition. Late Miocene silicic eruptions from the Owyhee Front volcanism, Bruneau-Jarbidge hotspot centre and the caldera forming rhyolite eruptions on the flanks of the OIG, deposited ash and volcanic detritus into these systems and were later reworked (Cummings et al. 2000).

\section{Field observations}

In the Northern Owyhee Mountains (SW Idaho) (Fig. 1b), the Rockville Segment of the JCR was partially erupted on to an unconsolidated/poorly consolidated sequence of the SCF (Bonnichsen et al. 2004) (Fig. 1b). The key exposure in this study is located on opposing sides of an $\sim 500 \mathrm{~m}$ long road cut (North and South transects, Fig. 2) along Route 95, located at the base of French John Hill (N 43 24' 26.1', W $116^{\circ} 51^{\prime}$ $54.4^{\prime \prime}$ ) (Fig. 1c). This exposure provides a vertical section, $\sim 30$ to $40 \mathrm{~m}$ high, through the rhyolite lava and underlying volcaniclastic succession, allowing for detailed examination of the interaction that occurred at this contact.

\section{Lithofacies of the Sucker Creek Formation}

The sediment substrate exposed in the road cut consists of various tuffs and reworked tuffs representing a succession of ash fall deposits deposited in both terrestrial and lacustrine environments. Ash was deposited into shallow bodies of water associated with fluvial systems and small, localised lakes connected to Lake Idaho (Branney et al. 2008) (Table 1). Subaerial exposure between the deposition events allows for the oxidation of the top of the unit and the possible development of a thin palaeosol, reflecting the ephemeral nature of the lacustrine system (Table 1; Fig. 3). The presence of a coarse, fluvial conglomerate unit (Fig. 2f), further supports the interpretation of a continually fluctuating system of small, ephemeral lakes, large fluvial streams and terrestrial environment. There is evidence for steep, pronounced topography, such as fault escarpments, due to the presence of a coarse mass flow deposit (volcaniclastic breccia).

Extensive liquefaction and fluidisation of the sediment substrate, due to the emplacement of the lava, has resulted in a chaotic mix of these volcaniclastic sediments, classified as a "megabreccia" by Bonnichsen et al. (2004). The volcaniclastic and sedimentary succession is divided into non-disrupted units (NU; that can be logged) and disrupted units (DU). From field relationships, the majority of the deformation occurs in the chaotic units above the NU logged in 


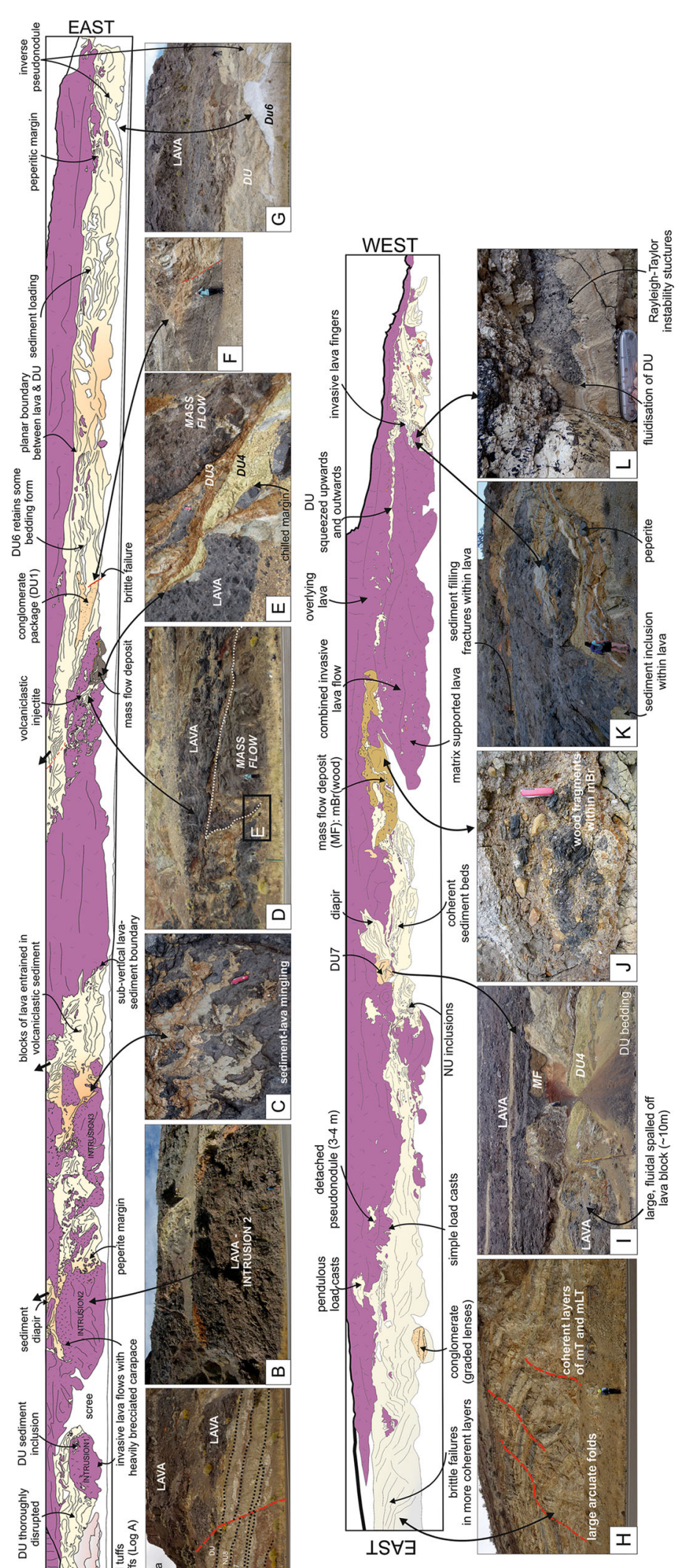

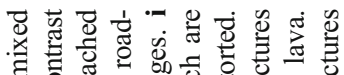

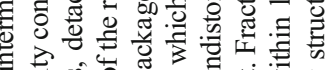

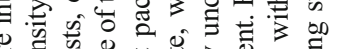

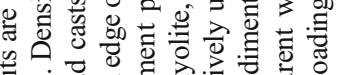

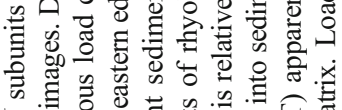

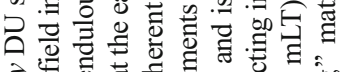

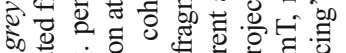

.

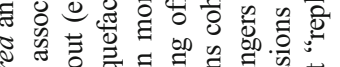

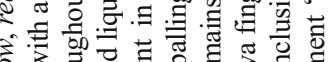

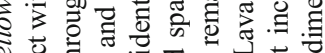

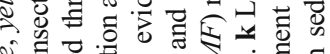

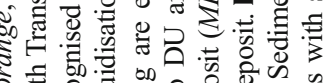

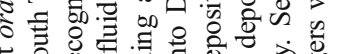

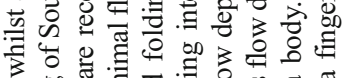

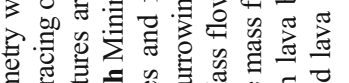

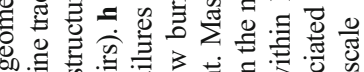

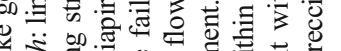

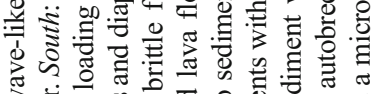

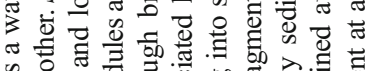

品 专

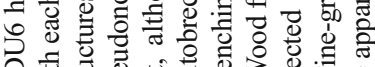

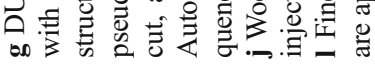

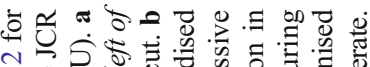

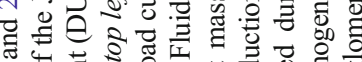

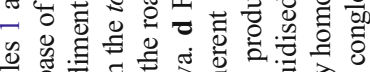

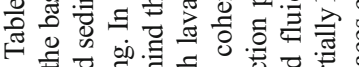

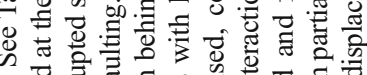

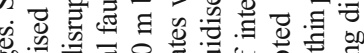

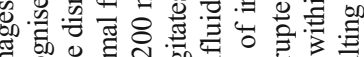

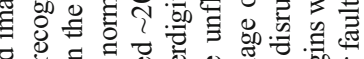

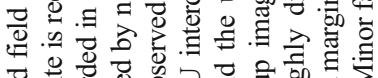

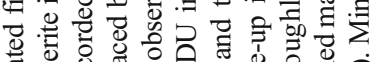

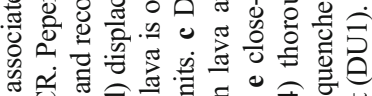

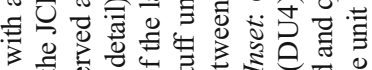

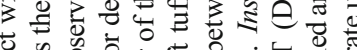

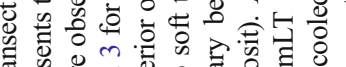

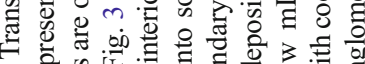

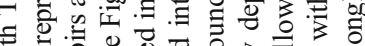

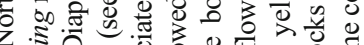

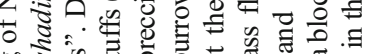

on

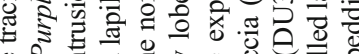

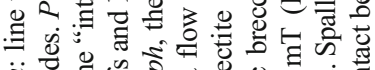

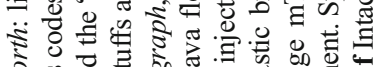

之.

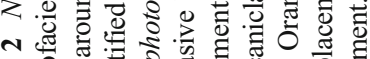

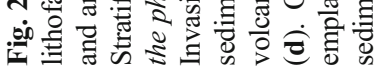


Table 1 Description and mechanisms of emplacement of the non-disrupted units (NU)

\begin{tabular}{|c|c|c|c|}
\hline Subunit & Thickness (m) & Description & Mechanism \\
\hline NU1 & 1.4 & $\begin{array}{l}\text { Light-grey, planar-stratified, pumice-rich lapilli } \\
\text { tuff (//sLTp). Variable and diffuse normal and }\end{array}$ & $\begin{array}{l}\text { Terrestrial ash fall deposit. Atypical SR-type } \\
\text { parallel-stratified rhyolitic ash fall deposit }\end{array}$ \\
\hline
\end{tabular}
reverse grading is evident and the unit is composed of alternating fine to coarse tuff and (Branney et al. 2008). lapilli tuff (between 4 and $14 \mathrm{~mm}$ ) (Fig. 3d, e). Towards the top $20 \mathrm{~cm}$ of the unit, fine, black, vitreous grains of obsidian and perlitic rhyolite become evident within the fine ash matrix.

Grey, massive, pumice-rich tuff (mTp) where the top $40 \mathrm{~cm}$ has been reddened and oxidised.

NU3

0.98

NU4

NU5

4

1.4

NU6

NU7 and NU8

3 and 2
Grey diffuse-stratified eutaxitic lapilli tuff (dsLTe). Contains $10 \%$ quartz crystals, $<5 \%$ vitrified lithics and $\sim 50 \%$ of pumice fiamme in an ash matrix.

Grey, crystal-rich (plagioclase feldspar) massive tuff (mTcr) where the top $20 \mathrm{~cm}$ has been reddened and oxidised.

Greenish-grey, massive siltstone (reworked mT) with no crystals or lithics.

White, massive tuff (mT). Clearly visible without a hand lens are large bubble cuspate shards (up to $15 \mathrm{~mm}$ ) within a frothy ash matrix.

Compositionally similar massive, coarse siltstones (reworked $\mathrm{mLT}$ ), however, the units are defined by reddened, oxidised tops. Minor mingling of NU8 and autobrecciated rhyolite lava is present within the top $40 \mathrm{~cm}$ of NU8.
Ash fall possibly deposited into a shallow body of water associated with the fluvial systems and small lakes connected to Lake Idaho (Cummings et al. 2000). Subaerial exposure between the deposition of NU2 and NU3 allows for oxidation of the top of the unit and the possible development of a thin palaeosol, reflecting the ephemeral nature of the lacustrine system.

Terrestrial deposition from a high temperature column (possibly collapsed to form a pyroclastic density current?). Pumice lapilli welded and/or sheared.

Ash fall possibly deposited into a shallow body of water associated with the fluvial systems and small lakes connected to Lake Idaho (Cummings et al. 2000). Subaerial exposure between the deposition of NU4 and NU5 allows for oxidation of the top of the unit and the possible development of a thin palaeosol, reflecting the ephemeral nature of the lacustrine system.

Ash fall deposit reworked by gentle aqueous currents in a lacustrine-type environment (Lake Idaho?).

Terrestrial ash fall deposit. Typical SR-type parallel-stratified rhyolitic ash fall deposit (Branney et al. 2008).

Ash fall deposit reworked by gentle aqueous currents in a lacustrine-type environment (Lake Idaho?).

$m$ massive, //s parallel-stratified, $d s$ diffusely stratified, $T$ tuff, $L T$ lapilli tuff, $p$ pumice rich, $c r$ crystal rich, $e$ eutaxitic

Fig. 3. The non-disrupted and disrupted units are mostly described using primary volcaniclastic terminology (after White and Houghton 2006). In cases where there is definitive evidence of reworking or fluvial/lacustrine deposition, we have used secondary volcaniclastic terminology.

\section{Non-disrupted units: intact volcaniclastic succession (NU1-8)}

At the western edge of the North Transect, the original stratigraphy of the NU has only been mildly disrupted by the overlying lava (Figs. 2a and 3; Table 1). The succession mostly represents typical Snake River-type volcanism defined by Branney et al. (2008), including abundant bi- and tri- cuspate, bubble wall shards, very few lithics and stratified beds, which are commonly less than $5 \mathrm{~m}$ thick (Branney et al. 2008; Ellis et al. 2013).

An ash fallout deposition is inferred for NU4-8 due to lateral consistency and lack of grading and/or stratification (Branney et al. 2008). NU5, NU7 and NU8 were likely deposited into a quiescent water body as these units are significantly thicker (2-4 m thick) than the other NU and lack 
Fig. 3 a Graphic log through layered non-disrupted units (NU). Location of A noted in Fig. 2a. A sequence of tuffs, lapilli tuffs and reworked siltstones (see Table 1 for details). An ephemeral lacustrine environment is suggested by the oxidised tops on some of the subunits and the massive structure of some of the units. b Disrupted units $(D U)$ interact with overlying lava forming blocky peperite. c Photomicrograph (ppl) of well-preserved bi- and tri- cuspate silicic shards in NU6, typical of Snake River volcanism (Branney et al. 2008). d Field photograph of stratified NU1. e

Photomicrograph (ppl) of NU1. Alternating tube-pumice-rich and ash-rich layers in non-welded tuff

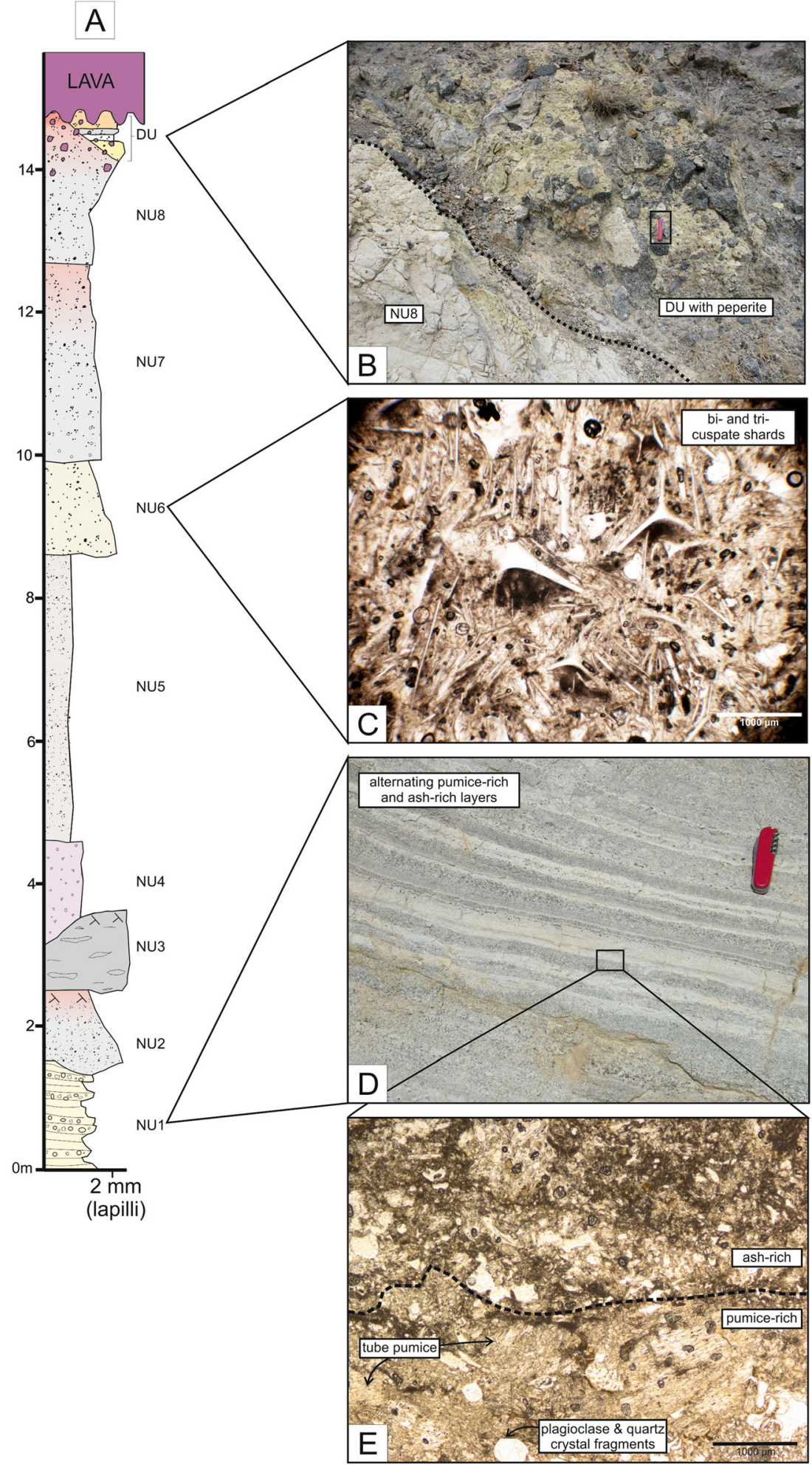

stratification. The cuspate shards in NU6 are on a centimetre scale indicating the vesicles or bubbles that formed during fragmentation were on a macroscopic scale (Branney et al. 2008). NU4-8 are compositionally and texturally similar (NU6 contains shards), indicating NU4-8 were erupted from the same or similar sources. Palaeosols between some of the units (Table 1) imply periods of volcanic quiescence between eruption and deposition of units. The indication of highly explosive eruptions and a similarity to other SRtype tuffs in basins south of the Snake River Plain (e.g. 

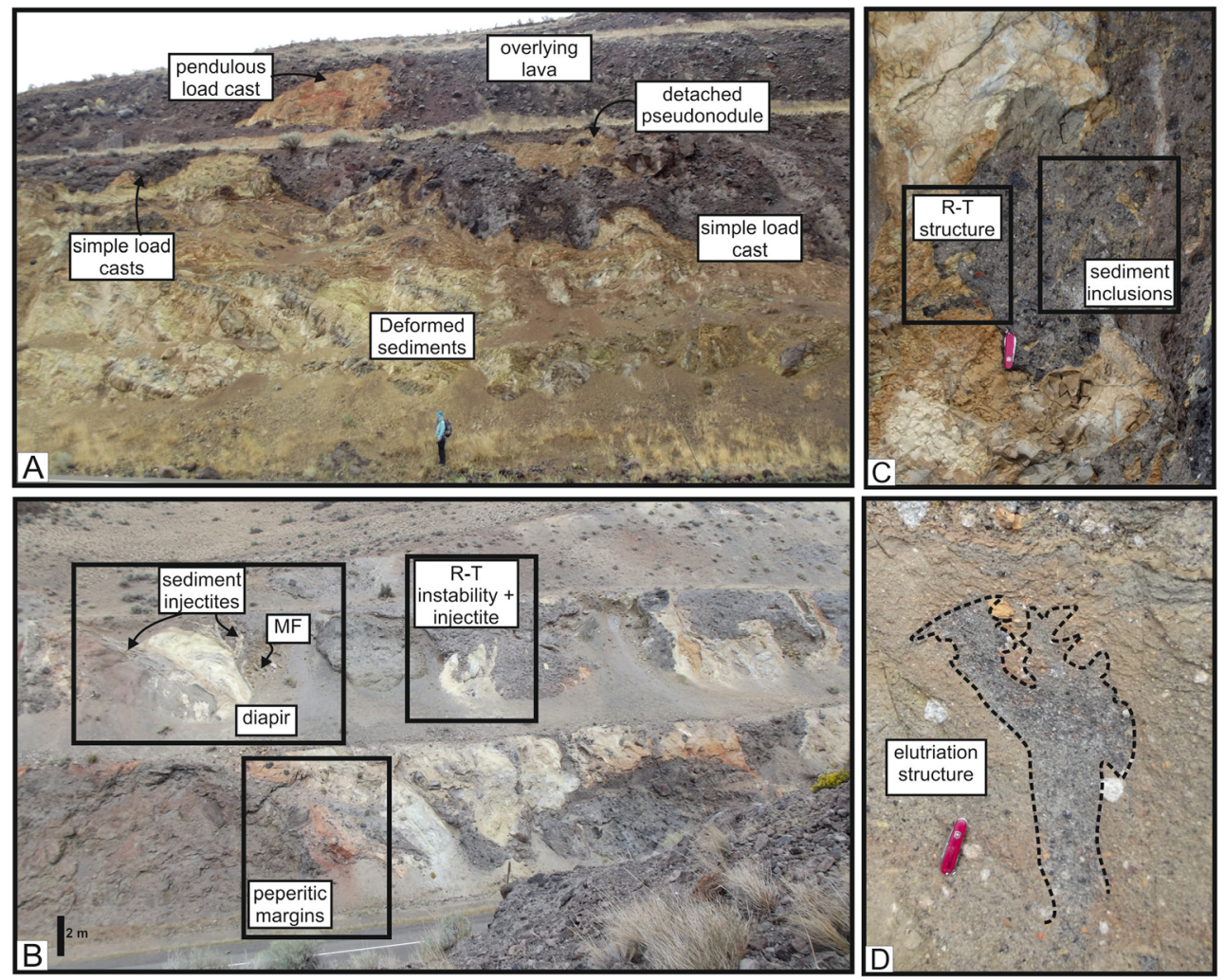

Fig. 4 Soft-sediment deformation features: a density contrast and loading structures forming at the interface between the JCR and underlying Sucker Creek Formation $(S C F)$. Simple and pendulous load casts and detached pseudonodules are evident (see Table 3 for formation mechanism). $M F$ mass flow deposit. b Remobilised sediment forms large fluidal diapirs. Disrupted sediment is injected into the rhyolite lava surrounding the diapirs. Peperitic margins in Fig 6a. $\mathbf{c}$ The lava-sediment boundary has a sinuous appearance and the two materials appear to have mingled as two contrasting fluids, providing evidence for Rayleigh-Taylor instabilities. Intensive mixing allowed sediment inclusions to become incorporated within the lava. Penknife is $10 \mathrm{~cm}$ long. d Dendritic elutriation structure that contains a higher relative proportion of juvenile rhyolite clasts and is coarser grained than the surrounding sediment, demonstrating vertical movement of fluids. Penknife is $10 \mathrm{~cm}$ long
Trapper Creek, Goose Creek, Big Cottonwood Canyon) (Perkins and Nash 2002; Branney et al. 2008; Ellis et al. 2013), including few lithics, thin layers $(<5 \mathrm{~m})$, evidence of reworking and shard-rich units, would suggest the source was related to volcanism associated with the BruneauJarbidge centre, $\sim 150 \mathrm{~km}$ to the southeast (Fig. 1a). Ash from the explosive stage of the Bruneau-Jarbidge eruptions was widely dispersed, correlating with thick metre scale ash deposits thousands of kilometres from the Snake River Plain (Perkins and Nash 2002).

Preservation of pumice-rich and eutaxitic units in NU1-3 is atypical for SR-type volcanism and implies the ash in these

Table 2 Composition and structure of the disrupted unit $(D U)$ subunits

\begin{tabular}{|c|c|c|c|c|c|c|c|}
\hline \multirow[t]{2}{*}{ Subunit } & \multirow[t]{2}{*}{ Nomenclature } & \multirow[t]{2}{*}{ Colour } & \multicolumn{4}{|l|}{ Composition } & \multirow[t]{2}{*}{ Structure } \\
\hline & & & Pumice (\%) & Crystals (\%) & Lithics $(\%)$ & Matrix (\%) & \\
\hline DU2 & dsTcr & White & 0 & 10 & 5 & 85 & Diffusely laminated $(<1 \mathrm{~cm})$ \\
\hline DU3 & $\mathrm{mTp}$ & Orange & $<5$ & 5 & 5 & $85-90$ & Massive, random fibrous pumice \\
\hline DU4 & mLTl & Yellow & 0 & $<5$ & 30 & 70 & Massive \\
\hline DU5 & $\mathrm{mT}$ & Grey & 10 & 10 & 0 & 80 & Massive \\
\hline DU6 & $\mathrm{mTp}$ & White & 10 & $<5$ & 0 & 85 (v. fine ash) & Massive \\
\hline DU7 & $\mathrm{mTcr}$ & Red/purple altering to green & $?$ & 10 & 0 & 90 & Massive \\
\hline
\end{tabular}

Mechanism of emplacement and chronological order cannot be accurately determined due to the thorough disruption of the subunits $m$ massive, $d s$ diffusely stratified, $T$ tuff, $L T$ lapilli tuff, $p$ pumice rich, $l$ lithic rich, $c r$ crystal rich 
units was derived from a different and potentially more proximal source than the later NU4-8. Between 12.6 and $10.5 \mathrm{Ma}$, widespread sedimentation in the OIG, including the deposition of the Sucker Creek Formation, coincided with eruption of caldera forming rhyolitic ignimbrites and extrusion of rhyolite flows that erupted from vents at the margins of the OIG (Cummings et al. 2000) (Fig. 1a). It is inferred that NU1-3 were sourced from volcanism related to the OIG, implying that the Sucker Creek Formation succession beneath the JCR had multiple ash sources.

The loading of the lava on to the partially consolidated volcaniclastic sediments (NU1-7) has caused the bedding of the sequence to sag beneath the overlying lava, creating large arcuate open folds in the intact stratigraphy (Fig. 2h). Where the intact stratigraphy is preserved, a series of normal and reverse faults are present (Fig. 2a, h). The displacement along these faults ranges from $10 \mathrm{~cm}$ to $3-4 \mathrm{~m}$.

\section{Disrupted units: deformation zone (DU1-7)}

Extensive churning and mixing of the subsequent units above NU8 has resulted in a complete loss of the original stratigraphy and therefore, a chronology and accurate interpretation of the deposition of these units cannot be determined (Fig. 4). The disrupted units are classified as one unit, DU, due to their overprinted textural parameters. Where possible, the DU is divided into subunits, DU1 to DU7, characterised in the field by colour, grain size and structure (Table 2; Figs. $3 \mathrm{~b}$ and 4). The thickness of the DU is $\sim 20-40 \mathrm{~m}$ (Fig. 2, North).

Subunit DU1 consists of a bedded conglomerate unit, comprising subrounded pebble-dominated packages interbedded with gravel dominated packages. The bedding in the conglomerate subunit remains intact despite DU1 being surrounded by highly deformed sediments of later DU (Fig. 2f). Interbeds are between 2 and $24 \mathrm{~cm}$ thick and are laterally discontinuous. Clasts within the pebble dominated packages are up to $14 \mathrm{~cm}$ across and comprise basalt, quartzite and rhyolite. Low gradient crossbeds consist of thin lenticular volcaniclastic sediment lenses of coarse sand grade. Crossbedding of pebble and gravel grades suggest a fluvial system with cyclical changes in energy. Sharp contacts with the surrounding DU indicate loading induced brittle deformation, suggesting partial consolidation pre-lava emplacement (Fig. 2f); however, locally, rounded basalt clasts $(<1$ to $9 \mathrm{~cm}$ ) from subunit DU1 have been separated from the subunit and incorporated into the surrounding mixture of DU.

\section{Mass flow deposit}

Incorporated locally within the DU, but overlying all the DU units, is a massive, matrix-supported volcaniclastic breccia

Table 3 Summary of deformation structures and the mobilisation mechanisms required to form such structures

\begin{tabular}{|c|c|c|c|c|c|c|}
\hline & & Structure & Figure & Definition & Trigger & $\begin{array}{l}\text { Soft-sediment } \\
\text { remobilisation } \\
\text { mechanism }\end{array}$ \\
\hline \multirow{5}{*}{ 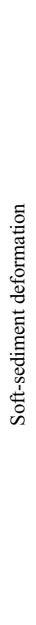 } & $=112=$ & Diapir & $4 \mathrm{~b}$ and $6 \mathrm{a}$ & $\begin{array}{l}\text { Deformation of a planar boundary caused by loading. Upward directed protrusion or } \\
\text { antiform, which can potentially disrupt overlying stratigraphy. Flame-like structure } \\
\text { (Mills 1983). }\end{array}$ & $\begin{array}{l}\text { Loading and } \\
\text { forceful } \\
\text { emplacement }\end{array}$ & Liquefaction \\
\hline & 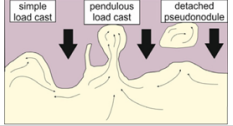 & $\begin{array}{l}\text { Loading structures } \\
\text { (load casts; detached } \\
\text { pseudonodule) }\end{array}$ & $4 a$ & $\begin{array}{l}\text { Density contrasts deform the interface between } 2 \text { layers. A spectrum of deformation } \\
\text { structures form. Simple load casts: upper layer is continuous, wavy interface. } \\
\text { Pendulous load casts: perpetuation of deformation process, attached to the upper layer } \\
\text { by a narrow neck. Detached pseudonodule: developed from pendulous load casts if the } \\
\text { rising of the lower layer is more vigorous than the sinking of load casts (Owen 2003). }\end{array}$ & $\begin{array}{l}\text { Loading and } \\
\text { density } \\
\text { contrast }\end{array}$ & Liquefaction \\
\hline & & $\mathrm{R}-\mathrm{T}$ instabilities & $4 \mathrm{c}$ & $\begin{array}{l}\text { Similar to the 2-layer system defined above, where both layers are liquefied } \\
\text { (Hindmarsh and Rijsdijk 2000). The instability is controlled by the less dense layer } \\
\text { (Mills 1983). "Swirly", highly convolute morphologies. }\end{array}$ & $\begin{array}{l}\text { Density } \\
\text { contrast }\end{array}$ & Liquefaction \\
\hline & & Sediment injectite & $2 \mathrm{~d}, \mathrm{e}$ & $\begin{array}{l}\text { Mobilised sediment that is able to penetrate into weaknesses in overlying strata (e.g. } \\
\text { fractures, faults, boundaries). }\end{array}$ & $\begin{array}{l}\text { Loading and } \\
\text { forceful } \\
\text { emplacement }\end{array}$ & Liquefaction \\
\hline & & Elutriation structure & $4 \mathrm{~d}$ & Vertically directed expulsion of fluid (Mills 1983). & $\begin{array}{l}\text { Loading and } \\
\text { heat }\end{array}$ & Fluidization \\
\hline \multirow{2}{*}{ 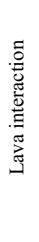 } & & Fracture injectite & $4 b$ and $6 f, g$ & $\begin{array}{l}\text { Opening of a brittle fracture due to cooling and quenching in a cooling body, which } \\
\text { reduces the lithostatic pressure, allowing for fluidisation of adjacent sediments and the } \\
\text { injection of fluidised sediments into the fracture (Kokelaar 2002). }\end{array}$ & Cooling & Fluidization \\
\hline & & Peperite & $6 a-d$ & $\begin{array}{l}\text { Rock formed essentially in situ by disintegration of magma intruding and mingling } \\
\text { with unconsolidated or poorly consolidated, typically wet sediments (White et al. } \\
2000 \text { ). Can form at margins of intrusions and base of lavas (and ignimbrites, Branney } \\
\text { et al. 2008). Rhyolite magmas produce blocky peperite textures, due to the high } \\
\text { viscosity of the magmas (Busby-Spera and White 1987; Dadd and Wagoner 2002). }\end{array}$ & Heat & Fluidization \\
\hline
\end{tabular}


(Fig. 2d, I) with large wood fragments $(\sim 15 \mathrm{~cm})$ (Fig. 2j). The breccia consists of granule to cobble size $(2 \mathrm{~mm}$ to $\sim 40 \mathrm{~cm})$ clasts that are subangular and subrounded and are mostly composed of rhyolite, basalt and tuff, in a fine-sand-grade matrix. Volcaniclastic sediment inclusions (from the older DU) are mingled within the breccia, and some of the inclusions retain internal, mildly deformed laminations (mm-scale).

\section{Soft-sediment deformation structures (DU2-7)}

A range of deformation structures are present in the sediment and are defined, and their formation mechanisms are summarised in Table 3. Further details of these structures are described below.

Diapiric ascent of sediment into the overlying lava is evident on both sides of the road-cut exposure, where giant simple and pendulous load casts (1-4 $\mathrm{m}$ in length) are present at the rhyolite-sediment interface (eastern margin of South Transect) (Fig. 4a). Locally, where the necks of the pendulous load casts have closed, detached pseudonodules of sediment have developed in the overlying lava (Woidt 1978; Owen 2003). The pseudonodules are metre-scale isolated zones of sediment incorporated into the rhyolite (Fig 4a). The sediment also forms large diapirs that extend vertically and penetrate the base of the overlying lava for up to $\sim 15-20 \mathrm{~m}$ (Fig. 4b). The boundary between the lava and the sediment diapirs is highly fluidal and the two materials appear to be mixing like two contrasting fluids (Fig. 4c). Locally, laminations and primary bedding are still preserved in the diapirs.

Sediment (DU2-4) has been forcefully injected into the boundary between the lava and the mass flow deposit on the north side of the road cut (Fig. 2d, e). The subvertical "injectite" extends for $\sim 10 \mathrm{~m}$, and grades from distinguishable subunits at the base to a dendritic form with thin sediment veins splaying into the adjacent lava unit at the top of the structure (Fig. 2d). The sediment subunits intimately interact with a range of boundary morphologies: planar and fluidal at the base of the injectite and increasingly more convoluted until separate subunits are indiscernible at the top of the injectite. Isolated rhyolite clasts are present in the injectites, spalled from the adjacent lava (Fig. 2e). Larger rhyolite clasts (greater than $10 \mathrm{~cm}$ ) have glassy rims, indicating hot emplacement into sediment (Fig. 2e).

Elutriation structures are present in the DU and demonstrate vertical movement of fluids (Fig. 4d) (Busby-Spera and White 1987). These fluid escape structures lack fines and are composed mainly of granule to cobble sized rhyolite fragments. The elutriation structures are on a decimetre scale and have a dendritic, lobate appearance.

Locally, the subunits of the deformed zone are discernible from one another. In particular, a very fine, white massive tuff (DU6) retains its coherency and has not been fluidised extensively like the other DU subunits. Locally, fragments of DU6 beds are isolated in homogenised DU. At the eastern margin of the North Transect, DU6 displays distinctive wave-like geometries. The other subunits of the DU surround the "waves", and isolated pseudonodules of detached DU6 are spalled off at the "wave crest" (Fig. 2g).

\section{Jump Creek Rhyolite lava}

The JCR lava extends northwards behind the road cut where it forms the French John Hill (Fig. 1c). Three prominent cliffs of this hill are seen $\sim 100 \mathrm{~m}$ to $300 \mathrm{~m}$ behind the road cut. The
Fig. 5 Features of rhyolite lava. a Flow banding in autobrecciated block ( $\sim 1.5 \mathrm{~m}$ long). Penknife (in box) is $10 \mathrm{~cm}$ long. b Matrixsupported flow-banded rhyolite autobreccia from the invasive conduit. c Photomicrograph (xpl) of sample taken from rhyolite in intrusion. Fractured plagioclase feldspar phenocrysts, demonstrating jigsaw fit, within fine, quartz-feldspar groundmass. d Photomicrograph (xpl) of sample taken from intrusion. Fractured plagioclase phenocryst (highlighted) was crushed between two rhyolite lava autobrecciated clasts
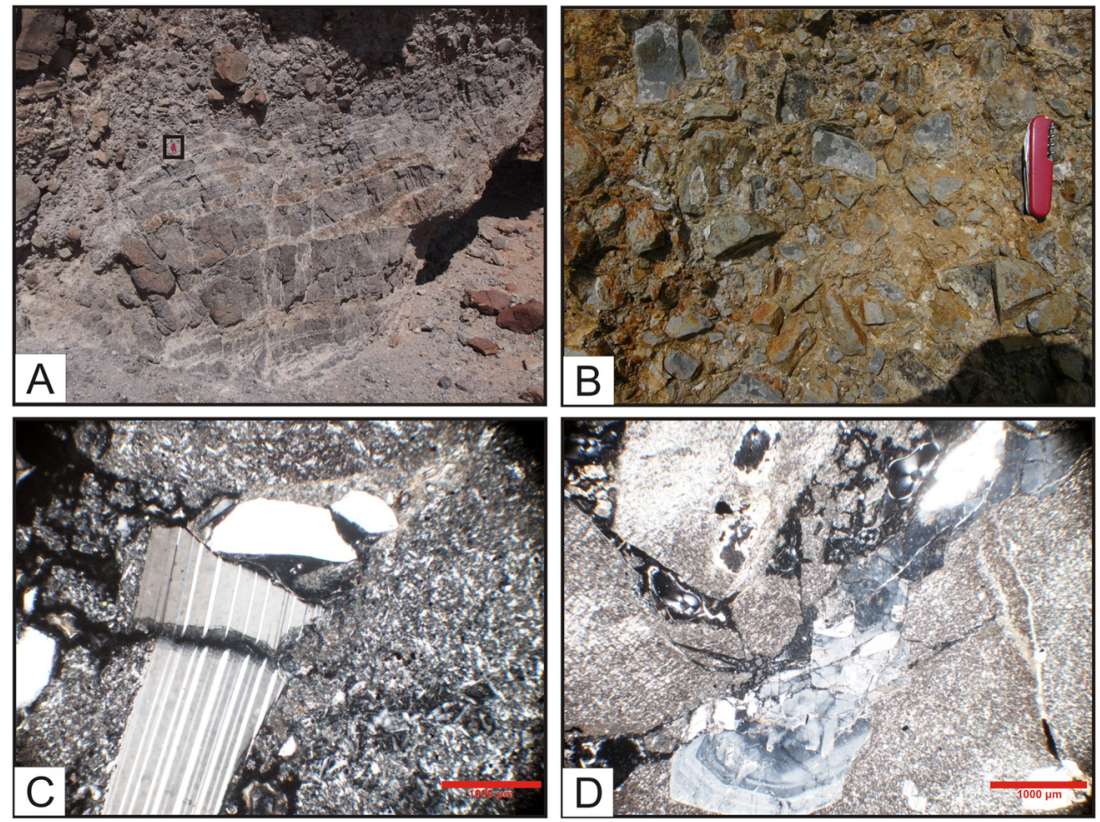
highest cliff ( $\left.\mathrm{N} 43^{\circ} 40^{\prime} 80.3^{\prime \prime}, \mathrm{W} 116^{\circ} 87^{\prime} 37.8^{\prime \prime}\right)$ comprises a massive porphyritic, microcrystalline rhyolite with thick columnar joints. On lower sections of this cliff, the rhyolite is more intensely fractured, marking the gradational boundary from coherent lava interior to the autobrecciated lava in cliffs further down slope, typical of SR-type rhyolite lava flows (Branney et al. 2008). Flow banding and plagioclase feldspar phenocrysts $(<12 \mathrm{~mm})$ are evident in the middle and bottom cliffs ( $\mathrm{N} 43^{\circ} 40^{\prime} 62.9^{\prime \prime}, \mathrm{W} 116^{\circ} 87^{\prime} 40.1^{\prime \prime}$ ). Flow banding within blocks is up to $60 \mathrm{~cm}$ wide and defined by glassy aphanitic bands (Fig. 5a). Bonnichsen et al. (2004) observed a high abundance of subvertical fractures here, which is unusual for the JCR, and suggests an unusual structural emplacement.

The rhyolite at road-cut height ( $\mathrm{N} 43^{\circ} 40^{\prime} 50.9^{\prime \prime}, \mathrm{W}$ $\left.116^{\circ} 87^{\prime} 08.5^{\prime \prime}\right)$ is a matrix-dominated and matrixsupported flow-banded rhyolite basal autobreccia that contains angular glassy blocks (maximum $1.5 \mathrm{~m}$ ) within a coarse granulated matrix (Fig. 5b). The crosssection in Fig. 2 (North) shows the steeply inclined boundary between the lava and sediment reflecting steep palaeotopography at the time of lava emplacement. Petrographic analysis of the autobrecciated rhyolite from the road cut shows angularly fragmented groundmass
Fig. 6 Lava-sediment interaction. a Blocky peperite margin surrounding intrusion. Peperite margin up to $10 \mathrm{~m}$ into sediment. Fluidal diapir (Fig. 4b) visible in the top left of the image. b Microscale peperite at lava-sediment interface. Fragmented rhyolite clasts $(<3 \mathrm{~cm})$ within sediment. c Photomicrograph of micro-scale peperite (ppl). Perlitic rhyolite clast (12 $\mathrm{mm}$ ) with angular, fractured edge on the left of the image. Fractured microclasts of perlitic rhyolite in a brown, indistinguishable groundmass on the right side of the image. $\mathbf{d}$ Isolated blocky rhyolite clasts in sediment. Clasts spalled $\sim 8 \mathrm{~m}$ from margin of lava. e Sediment $1.6 \mathrm{~m}$ from edge of lava. Sediment matrix comprises DU sediments,

phenocryst fragments (plagioclase feldspar), small rhyolite clasts $(<25 \mathrm{~mm})$ and subrounded quartz crystals. f Thin sediment vein near margin of lava intrusion $(\sim 2 \mathrm{~m})$ formed by injection of sediment into lava. g Photomicrograph (xpl) of the diffuse DU-lava boundary showing sediment filling fractures (highlighted by arrow) within a small rhyolite lava clast, reflecting small-scale cooling contraction granulation and forming a sediment vein. Crystal fragments (plagioclase and quartz) in the sedimentary matrix. h On the south side of the road cut, the invasive conduits become one (Fig. 2, South). Intense mixing of rhyolite autobreccia matrix with sediment results in a matrix-supported breccia with a high percentage of fluidal sediment inclusions and blocky rhyolite clasts
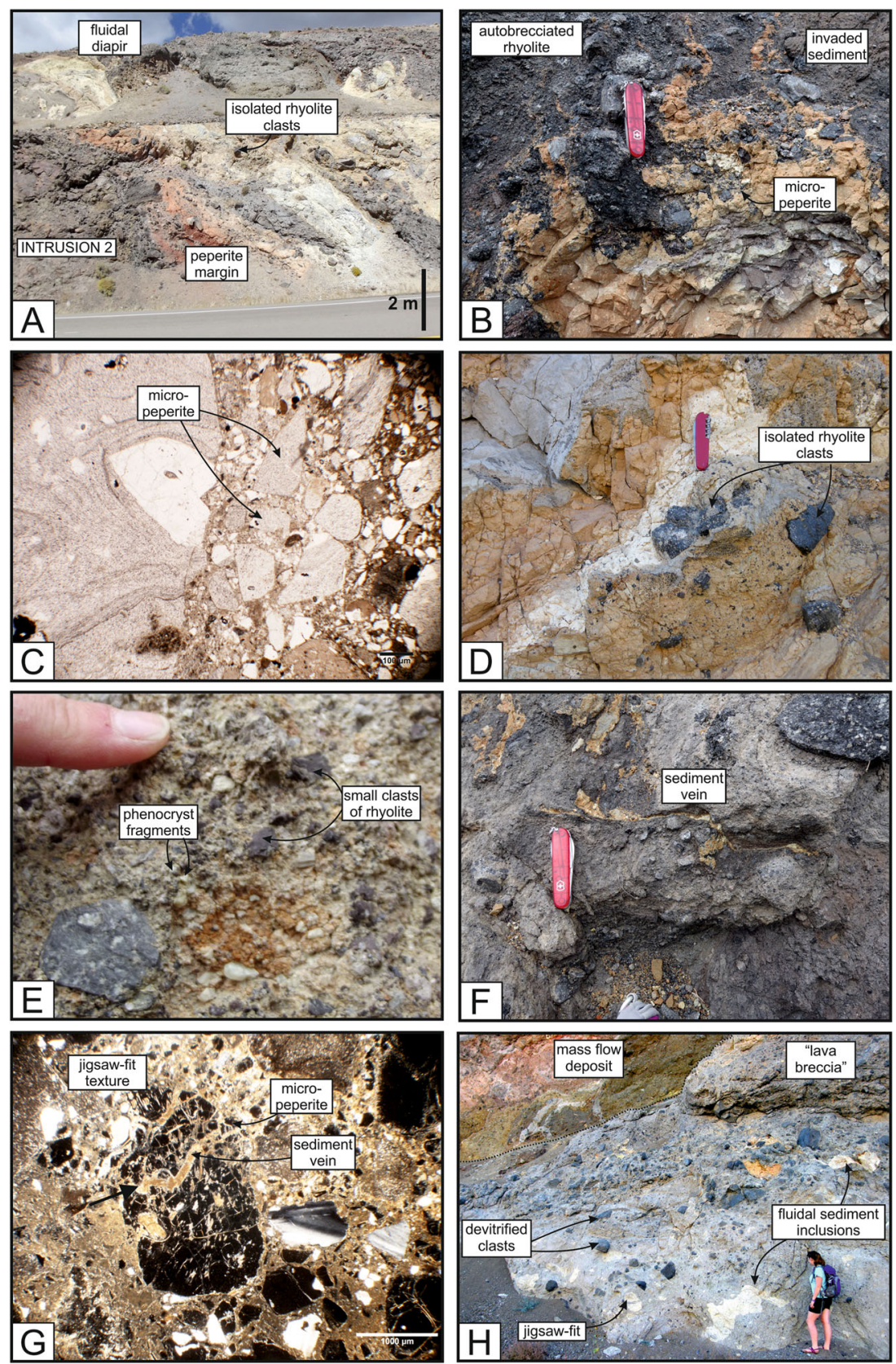
material with fragmented plagioclase and zoned alkali feldspar phenocrysts. Shearing between fractures has resulted in phenocrysts being sheared and crushed between autobrecciated clasts (Fig. 5c, d).

\section{Rhyolite-sediment interaction}

On the north side of the road cut, three shallow invasive lobes, fed by the extrusive lava flow, have forcefully invaded/ burrowed into the soft volcaniclastic substrate (DU; labelled on Fig. 2). These "intrusions" are annular shaped conduits (10-12 $\mathrm{m}$ in height) and are composed of clast-supported rhyolite autobreccia with angular, flow-banded blocks up to $3 \mathrm{~m}$. Associated with the invasive conduits, juvenile rhyolite lava clasts have thermally spalled off, rotated and commingled into the DU sediment mix, forming blocky peperite at a meso and micro-scale (Fig. 6a-c). Equant to subequant blocks are present up to $10 \mathrm{~m}$ away from the edge of the "intrusion" margin and are thoroughly mixed with the volcaniclastic sediment (Fig. 6d). Petrographically, the peperite margin consists of a very fine undifferentiated matrix containing cuspate shards, tube-pumice fragments, angular vesiculated pumice fragments, altered plagioclase phenocrysts, microlites, perlitic rhyolite microclasts, mineral fragments (plagioclase, alkali feldspar and quartz) and microcrystalline quartz filling veins and fractures (Fig. 6e, g). Perlitic textures are evident in thin section. Some rhyolite clasts and fragments exhibit "jigsaw" fit, where fine sediment veins separate individual clasts (Fig. 6f). In the larger clasts of rhyolite $(>1 \mathrm{~mm})$, the sediment has been injected into fractures and microfractures (Fig. $6 \mathrm{~g}$ ). The sediment extends into fractures between $<1 \mathrm{~mm}$ (microscale) and $1.75 \mathrm{~m}$. In the outer carapace of the shallow "intrusions" (2-3 m from the margin), lenticular sediment inclusions have been incorporated into the rhyolite lava $(<1 \mathrm{~m}$ in length) (Fig. 2c, $\mathrm{k}$ and $\mathrm{l})$. These sediment stringers make up $<1 \%$ of the clasts in the autobreccia.

On the south side of the road cut, the invasive lobes merge into one large "intrusion", $\sim 15 \mathrm{~m}$ in height and $125 \mathrm{~m}$ in length (Fig. 2, South). On the south side, the clast-supported autobreccia grades into a matrix-supported "lava breccia" and is paler, indicative of more intensive mingling with surrounding sediment (Fig. 6h). The rhyolite groundmass has commingled with the granular volcaniclastic sediments creating a homogenous matrix. Sediment inclusions are not restricted to the margins of the intrusion (like on the north side) but are distributed throughout. Here, the sediment inclusions have fluidal margins and contribute $\sim 25 \%$ of the total clast population, with the remaining $\sim 75 \%$ glassy rhyolite clasts (Fig. 6f). The rhyolite "lava breccia" invasively fingers into the disrupted sediment (up to $3 \mathrm{~m}$ in length) (Fig. 2k).

\section{Consolidation state of the SCF and triggers for subsurface mobilisation}

This case study presents evidence for three types of lavasediment interaction (Fig. 7), which occur simultaneously and cause complex disruption of the volcaniclastic facies

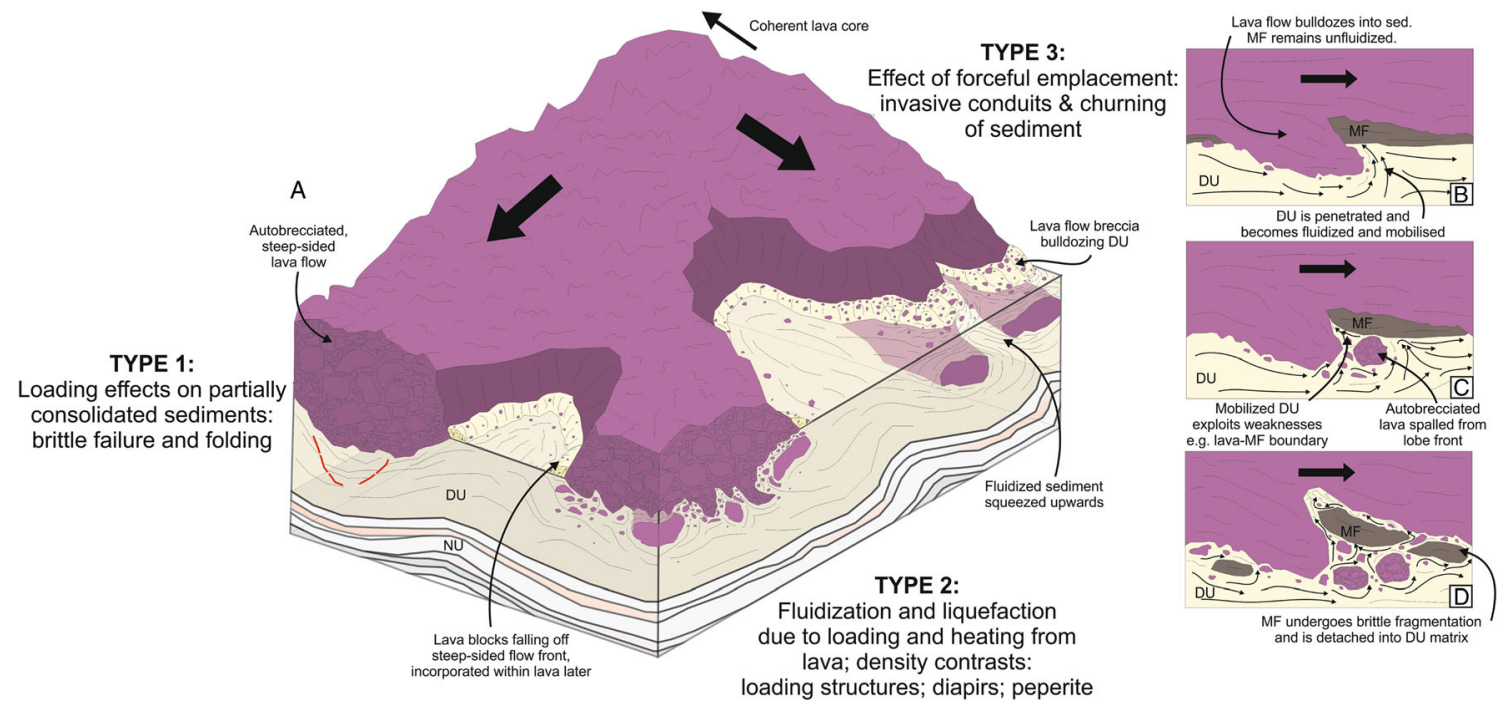

Fig. 7 a Schematic emplacement model, highlighting the three types of lava-sediment interaction. Type 1: loading of lava causes folding at the boundaries of the lava flow and brittle failure along discrete shear surfaces. This type affected the more consolidated sediments that retained some degree of mechanical strength. Folding of more cohesive sediments. Type 2: loading structures and peperite. Disrupted lavasediment interface. Type 3: the effects of forceful emplacement in unconsolidated sediments were diapiric ascent of sediment, invasive lava intrusions, and extensive churning and homogenization of sediment. Inset: types 2 and 3-b lava burrowed into and broke through localised MF (mass flow deposit) and intruded DU; c DU sediments were mobilised and injected into weaknesses and fractures within lava, aiding autobrecciation and exploiting the boundary between lava and MF. d Lava was spalled from the lava "intrusion" front and rotated and sheared into the DU sediment. Peperitic margins formed, which were further displaced by hypermobile sediment 
architecture: (1) brittle deformation structures and folds in the partially consolidated sediments (NU, DU1) (Fig. 2f, h), (2) loading structures (Fig. 4a) and peperite formation (Fig. 6a-c) and (3) extensive mobilisation and upward ascent of sediment into the overlying lava due to forceful emplacement, exploiting boundaries, churning and homogenising sediment (Figs. 2d, e, 4b and 6e). Here, we consider the physical properties of the SCF at the time of JCR emplacement to understand the scale of sediment mobilisation and the triggers of extensive subsurface remobilisation.

\section{Consolidation state of sediments and timing of lava emplacement}

The presence of a fluvial conglomerate unit (DU1) and thick lacustrine deposits (DU7 and DU8) has established that the SCF was deposited in a fluctuating fluvial and lacustrine-type environment. At the time of lava emplacement, it is suggested that the sediments remained considerably water saturated, allowing the sediments to be fluidised effectively and contributing to the effects of dewatering (elutriation structures, Fig. 4d) and peperite formation (Fig. 6a-d; Table 3). A differential response to liquefaction and fluidisation occurs between the two facies, the NU and the DU. The DU displays complex ductile soft-sediment deformation (Fig. 4a-c; Table 3), implying that the DU was completely unconsolidated at the time of the Owyhee Front Rhyolites (the JCR) volcanism and was rapidly loaded by the JCR. Brittle failures are present in the NU and the conglomerate package (DU1) (Fig. 2a, h), which are estimated to have been buried by up to $20 \mathrm{~m}$. Brittle deformation can occur in cohesionless sediments along discrete shear surfaces, during rapid loading events where pore pressure is sufficiently high (Maltman 1984, 1987; Owen 1987, 2003). However, the conglomerate subunit (DU1) is considered a cohesive unit, implying partial consolidation of the NU before lava emplacement. Folding of the NU also suggests that sediments in the non-disrupted beds retain some coherency.

\section{Triggers}

Due to the scale of the soft-sediment deformation features, it is important to consider the triggers and mechanisms of how the sediments beneath the JCR were mobilised (Table 3).

\section{Loading and heat}

Subsurface mobilisation of sediments can occur if sediments become liquefied or fluidised (Maltman and Bolton 2003). The height of vertical sediment displacement at the road cut (fluidal diapirs up to $15 \mathrm{~m}$ ) (Fig. 4a) suggests extensive liquefaction (Table 3). There are two proposed mechanisms for extensive liquefaction in the SCF. Firstly, the liquefaction is triggered by penecontemporaneous loading of the lava, instantaneously overburdening the sediments and increasing hydrostatic pore pressure above critical state (Anketell et al. 1970; Jones and Omoto 2000). Secondly, unlike other examples of loading triggers, such as cyclical (e.g. waves) (Pestana et al. 2000; Alfaro et al. 2002), mass flows (Postma 1984; Owen 1996) and glacial (Le Heron et al. 2005), lavainduced loading is also associated with a temperature increase in the underlying sediments. Numerical models suggest that rhyolite lava flows hundreds of metres thick, like the JCR, can retain heat for decades by forming a top carapace, locking in heat, and increasing their ability to produce internal latent heat (Manley 1992). Correspondingly, models testing the cooling rates of Snake River Plain rhyolite ignimbrites using groundmass crystallisation, have indicated that the base of the $60 \mathrm{~m}$ Grey's Landing Ignimbrite (Central Snake River Plain) remained above $400{ }^{\circ} \mathrm{C}$ for on the order of 10 years (Ellis et al. 2015). If rhyolites can stay molten or semi-molten at the base for decades, porewater in the underlying substrate can cross the phase boundary, from liquid to vapour for extended periods of time (Kokelaar 1982). In the SCF, this phase change increased the hydrostatic pore pressure of the vapoursupported grains allowing for extensive and prolonged liquefaction.

Both loading induced and heat-induced mobilisation mechanisms are proposed to occur simultaneously, where loading of the JCR on to the SCF instigated a pressure gradient that was sufficient to allow for voluminous vertical sediment migration. Such vigorous and continuous liquefaction would support diapirism on the scales we see beneath the JCR (Fig. 4a, b). The diapiric ascent of sediment formed metrescale pendulous load casts (Fig. 4a), detached sediment pseudonodules (Fig. 4a) and large, 15-20 m diapirs (Fig. 4b). Liquefied sediments were also forced upwards, penetrating and exploiting boundaries, forming sediment injectites (Fig. 2d, e). The dendritic nature of the injectites reflects the waning energy of the upward projecting sediment.

Fluidisation requires a continuous source of fluid and a sustained heat source to inhibit condensation of the vapour produced in sediments due to heating (Kokelaar 1982; Owen et al. 2011). The basal section of the thick JCR provided a sustained heat source for continuous vaporisation of pore fluids (Kokelaar 1982). Localised heating and/or fracture induced pressure release, vaporised small volumes of fluid, transmitted upwards forming vertical, fine-depleted elutriation structures (Fig. 4d; Table 3) and peperite (Fig. 6a-d; Table 3) (Kokelaar 1982; Busby-Spera and White 1987; Skilling et al. 2002).

\section{Density contrasts}

Reverse-density structures formed at the interface between the semi-molten rhyolite lava $\left(2.49 \mathrm{~g} / \mathrm{cm}^{3}\right)$ and the partially unconsolidated, liquefied volcaniclastic sediment (1.36 to 
$\left.1.65 \mathrm{~g} / \mathrm{cm}^{3}\right)$. The interface became unstable, representing a Rayleigh-Taylor (R-T) instability (Daly 1967; Allen 1982; Hall and Els 2002) and simple, planar boundaries between the two materials deformed into various types of load structures (e.g. Anketell et al. 1970; Allen 1982; Mills 1983; Owen 2003). Negative buoyancy controls the downward movement of rhyolite lava into the sediment and positive buoyancy controls the upward movement of the sediment. When the sediments in the DU are liquified (by mechanisms outlined above), the two fluids can interact. The turbulent mixing and "swirling" of the two fluids produces highly convolute and fluidal morphologies (Fig. 4c). If the rhyolite cools or the sediment solidifies, the R-T structures can no longer form and only true load structures (load casts, pseudonodules etc.) develop (Owen 2003).

The structure of DU6 remains fairly intact, with distinctive wave-like geometries (Fig. 2g), unlike the malleable DU sediments. The very fine-grained nature of DU6 suggests it is less thixotropic than the rest of the DU. The tightly spaced grains limit the volume of porewater, decreasing the probability for liquefaction. Consequently, DU6 retains significant residual shear strength in response to loading and liquefaction and so can only deform in a plastic manner (Owen 2003). As the fluidised sediments flowed over the internally coherent DU6, shear instabilities were generated across the
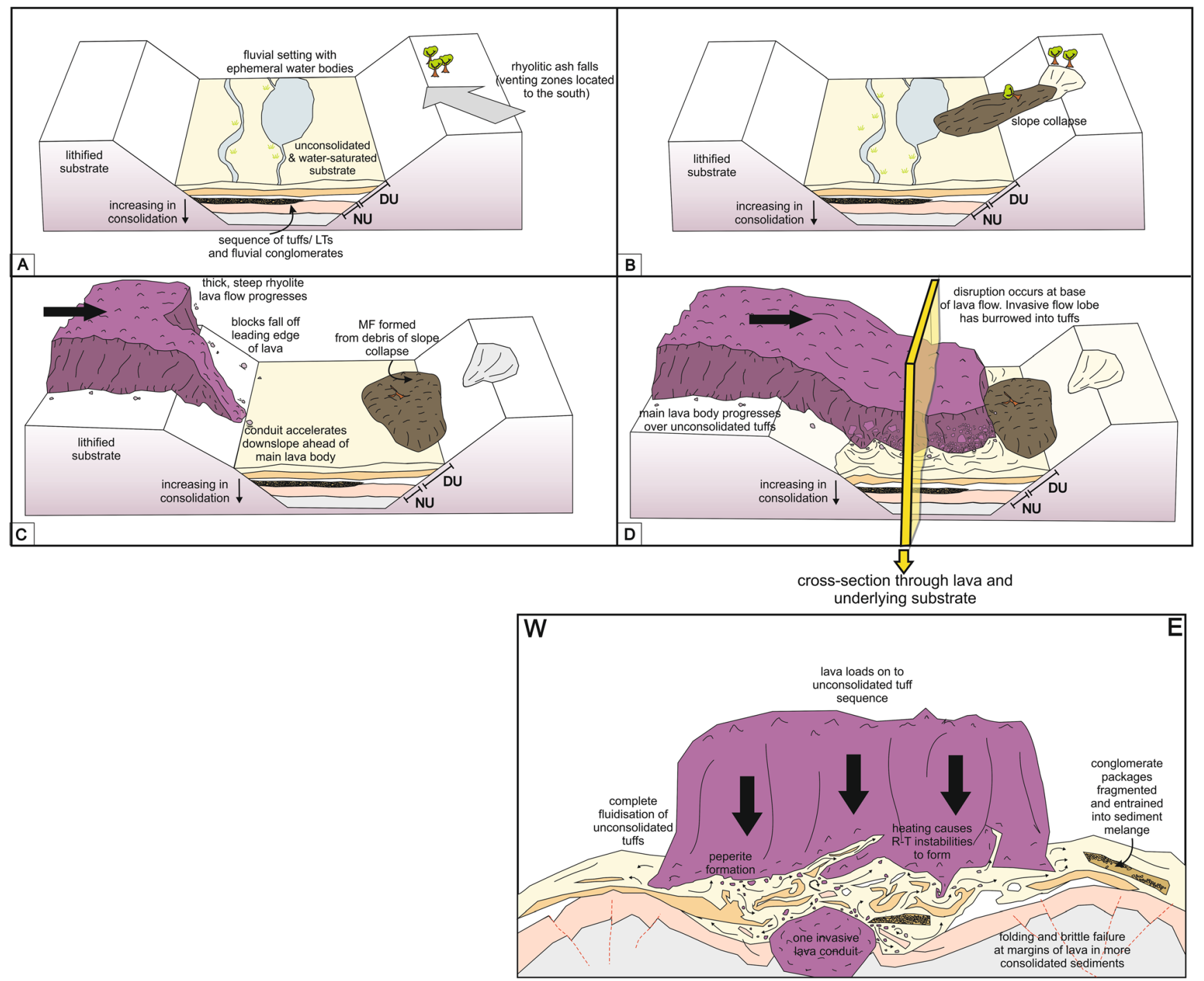

Fig. 8 Temporal model showing emplacement of the Jump Creek Rhyolite on to the Sucker Creek Formation and how topography controlled the scale of disruption. a The Sucker Creek Formation was deposited predominantly as a series of rhyolitic ash falls and conglomerate units reworked by lacustrine or fluvial processes. b Mass flow/debris flow deposit at the side of a valley incorporating plant debris. c Lava flowed over steep topography and accelerated. d Lava intruded into soft sediment to form extrusively fed intrusions. The main body of the JCR flowed over the top of the Sucker Creek Formation; Inset: Crosssection through lava shows soft-sediment deformation occurring at the base of the rhyolite lava flow. An individual "intrusion" is shown here 
interface between the two subunits and wave-like geometries were formed. These geometries may also be exaggerated by a relatively significant density contrast between DU6 and the other DU sediments. The result of shearing and this density contrast is the deformation of the DU6 interface, forming the wave-like structures (Fig. 2g) (Owen 2003).

\section{Forceful emplacement of JCR}

Extrusively fed rhyolite intrusions have bulldozed into the partially consolidated SCF, subsequently inflated and squeezed liquified tuffs into lobate, vertical diapirs (Fig. 4b), which propagated into the base of the main body of the lava flow. Invasive lava flows have been documented in komatiitic lavas and are explained by a large density contrast between the lava and partially unconsolidated sediment $\left(1.6-1.8 \mathrm{~g} / \mathrm{cm}^{3}\right)$ (Beresford and Cas 2001). In the case of the JCR, the three exposed intrusions, and extensive sediment disruption, are localised beneath the main lava body. Due to the large volumes of sediment displaced and the steep angle of intrusion (Fig. 2, North; "Soft-sediment deformation structures (DU2-7)"), it is suggested that a further "trigger" was required for the lava to abruptly intrude into the sediment. The formation of the intrusions is attributed here to an abrupt change in the underlying substrate to the less dense, soft volcaniclastic sediments of the SCF. This relatively abrupt transition can be explained by the presence of a steep valley side or fault escarpment (Bonnichsen et al. 2004) (Fig. 8). Rifting of the WSRP would have formed fault escarpments creating the steep topography suggested here ("The Jump Creek Rhyolite lava (11.1 $\pm 0.2 \mathrm{Ma})$ "). Bonnichsen et al. (2004) attribute prevalent subvertical fractures observed in the road cut (uncommon for the JCR) to an unusual structural emplacement, such as it having "cascaded" into a palaeocanyon. The localised occurrence of the volcaniclastic breccia with wood fragments (mass flow deposit) (Fig. 2j) also suggests debris (angular boulders, pebbles and plant material) was washed/collapsed down a steep slope into a valley (Fig. 8). A change in topography would promote relatively forceful emplacement of a comparatively coherent lava lobe front into the sediment. The lava extended into three distinct channels forming the three extrusively fed intrusions (Fig. 2, North). An increase in lava flow velocity would have been able to force sediment upwards and churn the sediment in the extensive manner that is observed at the road cut (Figs. 4 and $8 \mathrm{e}$ ). Density contrasts between the rhyolite and SCF would have also aided the downward intrusion of the rhyolite lava.

\section{Peperite formation and dispersal}

As the JCR cooled on contact with the SCF, it quenched at the margins of the rhyolite lava and opened angular fractures, relieving pressure in the surrounding host sediment and vaporising pore fluids (Kokelaar 1982; Hanson and Wilson 1993; Doyle 2000; Skilling et al. 2002). Sediment was injected into the newly opened fractures in the rhyolite (Fig. 6e), allowing for entrainment of isolated sediment inclusions into the lava conduits and in situ fragmentation of rhyolite (Fig. 6e) (Skilling et al. 2002). The result is peperite with a jigsaw fit texture and fine sediment veins separating individual clasts (Fig. 6f, g). Petrographic analysis of samples taken from the peperitic margins of the conduits shows that in situ fragmentation is scale invariant, occurring on both micro- and meso-scales (Fig. 6a, b). Small-scale contraction granulation has shattered blocks of rhyolite into subcentimetre juvenile rhyolite fragments (with perlitic textures), which have been incorporated into the sediment matrix (Fig. 6c, e) and remobilised away from the margin.

\section{Dispersal of the peperitic margin}

In the JCR, widely dispersed juvenile clasts are observed (Fig. 6a, d) (Hanson and Wilson 1993). Dispersal occurs as liquefied and hypermobile sediments (see "Triggers") entrain juvenile clasts and phenocrysts and displace this pre-existing peperite away from the lava margin into the partially homogenised sediments by non-explosive mechanisms (Hanson and Wilson 1993; Skilling et al. 2002). Similar features are documented surrounding rhyolite sills, demonstrating a spectrum of dispersal patterns and scales, from micro jigsaw fit fractures in rhyolite to widely dispersed juvenile clasts (e.g. Hanson and Wilson 1993; Hanson and Hargrove 1999; Németh et al. 2008). The inflation of the "intrusions" would have caused further disruption, squeezing the sediment upwards and entraining and displacing the pre-existing peperite away from the site of formation.

\section{Conclusions}

A road cut exposure in the Owyhee Mountains, allows analysis of processes that took place when a Late Miocene (11.1 $\pm 0.1 \mathrm{Ma}$ ) rhyolite lava flow of the Jump Creek Formation (the Rockville Segment) rapidly loaded on to a water-saturated and unconsolidated succession of the Sucker Creek Formation. Evidence for reworking and the presence of a fluvial conglomerate unit indicate the Sucker Creek Formation was deposited in a series of lakes and rivers associated with Lake Idaho. A mass flow deposit, the steep lava-sediment boundary, bulldozing of extrusively fed intrusions and highly mobilised sediments indicate that the rhyolite flowed over steep topography and was forcefully emplaced into the saturated, unconsolidated sediment. The extrusive lava-fed intrusions propagated into the sediment. 
Emplacement of the JCR on to the Sucker Creek Formation induced extensive fluidisation, liquefaction and subsurface remobilisation in the shallow volcaniclastic sediments (DU; 0-20 m) and generated a range of large soft-sediment deformation structures (diapirs, simple load casts, pendulous load casts and detached pseudonodules, elutriation structures) and Rayleigh-Taylor instability structures. Peperite was also formed at the base of the JCR and around the extrusively fed intrusions. In the more consolidated and coherent sediments (NU; 20-30 m), the loading induced brittle faults and large folds formed. The interaction between the JCR and underlying substrate demonstrates how large lava bodies can extensively disrupt sediments and form significant lateral and vertical discontinuities that complicate volcanic facies architecture.

Acknowledgements This manuscript was written whilst CM held a University of Glasgow PhD College Scholarship. We appreciate the constructive reviews of Karoly Nemeth, Ben Ellis and John Wolff as well as the associate editor, Pierre-Simon Ross.

Open Access This article is distributed under the terms of the Creative Commons Attribution 4.0 International License (http:// creativecommons.org/licenses/by/4.0/), which permits unrestricted use, distribution, and reproduction in any medium, provided you give appropriate credit to the original author(s) and the source, provide a link to the Creative Commons license, and indicate if changes were made.

\section{References}

Alfaro P, Delgado J, Estévez A, Molina J, Moretti M, Soria J (2002) Liquefaction and fluidisation structures in Messinian storm deposits (Bajo Segura Basin, Betic Cordillera, southern Spain). Int J Earth Sci 91:505-513

Allen JRL (1982) Liquidization, liquidized sediment, and the sedimentation of dense particle dispersions. In: Sedimentary structures: their character and physical basis. Developments in sedimentology. 30B Amsterdam, Elsevier. ISBN: 978-0-444-41945-3

Altaner SP, Grim RE (1990) Mineralogy, chemistry, and diagenesis of tuffs in the Sucker Creek Formation (Miocene), Eastern Oregon. Clay Clay Miner 38:561-572

Anketell JM, Cegla J, Dzulynski S (1970) On the deformational structures in systems with reversed density gradients. Ann Soc Géol Pol 40:3-29

Armstrong RL, Harakal JE, Neill WM (1980) K-Ar dating of Snake River Plain (Idaho) volcanic rocks - new results. Isochron 27:5-10

Beresford SW, Cas RA (2001) Komatiitic invasive lava flows, Kambalda, Western Australia. Can Mineral 39:525-535

Bonnichsen B (1982) Rhyolite lava flows in the Bruneau-Jarbidge eruptive center, southwestern Idaho: cenozoic geology of Idaho. Idaho Bur Mines Geol Bull 26:283-320

Bonnichsen B, Kauffman DF (1987) Physical features of rhyolite lava flows in the Snake River Plain volcanic province, southwestern Idaho. Geol Soc Am Spec Pap 212:119-145

Bonnichsen B, McCurry M., Godchaux MM (2004) Miocene Snake River Plain Rhyolites of the Owyhee Front, Owyhee County, Idaho. In: Haller KM and Wood SH (eds) Geological field trips in Southern Idaho, Eastern Oregon, and Northern Nevada: Geological Society of America. Rocky Mountain Section. Meeting and Geological Society of America. pp 156-175
Bonnichsen B, Godchaux MM (compilers) (2006) Geologic map of the Murphy $30^{\prime} \times 60^{\prime}$ Quadrangle, Ada, Canyon, Elmore, and Owyhee Counties, Idaho: Idaho Geological Society, scale 1:100000

Bonnichsen B, Leeman WP, Honjo N, McIntosh WC, Godchaux MM (2008) Miocene silicic volcanism in southwestern Idaho: geochronology, geochemistry, and evolution of the central Snake River Plain. Bull Volcanol 70:315-342

Branney MJ, Bonnichsen B, Andrews GDM, Ellis B, Barry TL, McCurry M (2008) 'Snake River (SR)-type' volcanism at the Yellowstone hotspot track: distinctive products from unusual, high-temperature silicic super-eruptions. Bull Volcanol 70:293-314

Busby-Spera CJ, White JD (1987) Variation in peperite textures associated with differing host-sediment properties. Bull Volcanol 49:765776

Christiansen RL, Lipman PW (1966) Emplacement and thermal history of a rhyolite lava flow near Fortymile Canyon, southern Nevada. Geol Soc Am Bull 77:671-684

Cummings ML, Evans JG, Ferns ML, Lees KR (2000) Stratigraphic and structural evolution of the middle Miocene synvolcanic OregonIdaho graben. Geol Soc Am Bul 112:668-682

Dadd KA (1992) Structures within large volume rhyolite lava flows of the Devonian Comerong Volcanics, southeastern Australia, and the Pleistocene Ngongotaha lava dome, New Zealand. J Volcanol Geotherm Res 54:33-51

Dadd KA, Van Wagoner NA (2002) Magma composition and viscosity as controls on peperite texture: an example from Passamaquoddy Bay, southeastern Canada. J Volcanol Geotherm Res 114:63-80

Daly BJ (1967) Numerical study of two fluid Rayleigh Taylor instability. Phys Fluids 10:297-307

Donaire T, Sáez R, Pascual E (2002) Rhyolitic globular peperites from the Aznalcóllar mining district (Iberian Pyrite Belt, Spain): physical and chemical controls. J Volcanol Geotherm Res 114:119-128

Doyle MG (2000) Clast shape and textural associations in peperite as a guide to hydromagmatic interactions: Upper Permian basaltic and basaltic andesite examples from Kiama, Australia. Aust J Earth Sci 47:167-177

Ellis BS, Wolff JA, Boroughs S, Mark DF, Starkel WA, Bonnichsen B (2013) Rhyolitic volcanism of the central Snake River Plain: a review. Bull Volcanol 75:1-19

Ellis BS, Cordonnier B, Rowe MC, Szymanowski D, Bachmann O, Andrews GDM (2015) Groundmass crystallisation and cooling rates of lava-like ignimbrites: the Grey's Landing ignimbrite, southern Idaho, USA. Bull Volcanol 77:1-15

Hall RCB, Els BG (2002) The origin and significance of load-induced deformation structures in soft-sediment and lava at the base of the Archaean Ventersdorp Supergroup, South Africa. J Afr Earth Sci 35: 135-145

Hanson RE, Hargrove US (1999) Processes of magma/wet sediment interaction in a large-scale Jurassic andesitic peperite complex, northern Sierra Nevada, California. Bull Volcanol 60:610-626

Hanson RE, Schweickert RA (1982) Chilling and brecciation of a Devonian rhyolite sill intruded into wet sediments, northern Sierra Nevada, California. J Geol 90:717-724

Hanson RE, Wilson TJ (1993) Large-scale rhyolite peperites (Jurassic, southern Chile). J Volcanol Geotherm Res 54:247-264

Henry CD, Price JG, Rubin JN, Laubach SE (1990) Case study of an extensive silicic lava: the Bracks Rhyolite, Trans-Pecos Texas. J Volcanol Geotherm Res 43:113-132

Jones AP, Omoto K (2000) Towards establishing criteria for identifying trigger mechanisms for soft sediment deformation: a case study of Late Pleistocene lacustrine sands and clays, Onikobe and Nakayamadaira Basins, northeastern Japan. Sedimentology 47: $1211-1226$

Kimmel PG (1982) Stratigraphy, age, and tectonic setting of the MiocenePliocene lacustrine sediments of the western Snake River Plain, 
Oregon and Idaho. Cenozoic geology of Idaho. Idaho Bur Mines Geol Bull 26:559-578

LR, Green AR, Hagood AR, Johnson AM, McMurray JM, Russell RG, Weeden DA (1965) Cenozoic stratigraphy of the Owyhee region, southeastern Oregon: Eugene, University of Oregon Museum of Natural History Bulletin 1, 45

Kokelaar BP (1982) Fluidisation of wet sediments during the emplacement and cooling of various igneous bodies. J Geol Soc 139:21-33

Le Heron DP, Sutcliffe OE, Whittington RJ, Craig J (2005) The origins of glacially related soft-sediment deformation structures in Upper Ordovician glaciogenic rocks: implication for ice-sheet dynamics. Palaeogeogr Palaeoclimatol Palaeoecol 218:75-103

Lewis RS, Link PK, Stanford LR, Long SP (compilers) (2012) Geologic map of Idaho. Idaho Geological Survey. 1:750,000. ISBN: 978-155765-118-1

Maltman A (1984) On the term "soft-sediment deformation". J Struct Geol 6:589-592

Maltman AJ (1987) Shear zones in argillaceous sediments-an experimental study. Geol Soc Lond Spec Publ 29:77-87

Maltman AJ, Bolton A (2003) How sediments become mobilised. Geol Soc Lond Spec Publ 216:9-20

Manley CR (1992) Extended cooling and viscous flow of large, hot rhyolite lavas: implications of numerical modeling results. J Volcanol Geotherm Res 53:27-46

Manley CR (1995) How voluminous rhyolite lavas mimic rheomorphic ignimbrites: eruptive style, emplacement conditions, and formation of tuff-like textures. Geology 23:349-352

Manley CR (1996) Physical volcanology of a voluminous rhyolite lava flow: the Badlands lava, Owyhee Plateau, southwestern Idaho. J Volcanol Geotherm Res 71:129-153

Mills PC (1983) Genesis and diagnostic value of soft-sediment deformation structures - a review. Sediment Geol 35:83-104

Needham RS (1978) Giant scale hydroplastic deformation structures formed by the loading of basalt onto water saturated sand, Middle Proterozoic, Northern Territory: Australia. Sedimentology 25:285295

Németh K, Pécskay Z, Martin U, Gméling K, Molnár F, Cronin SJ (2008) Hyaloclastites, peperites and soft-sediment deformation textures of a shallow subaqueous Miocene rhyolitic dome-cryptodome complex, Pálháza, Hungary. Geol Soc Lond Spec Publ 302:63-86

Owen G (1987) Deformation processes in unconsolidated sands: Geological Society, London, Special Publications 29: 11-24. In: Jones ME, Preston RMF (eds) Deformation of sediments and sedimentary rocks. doi: 10.1144/GSL.SP.1987.029.01.02

Owen G (1996) Experimental soft sediment deformation: structures formed by the liquefaction of unconsolidated sands and some ancient examples. Sedimentology 43:279-293

Owen G (2003) Load structures: gravity-driven sediment mobilisation in the shallow subsurface: Geological Society, London, Special
Publications 216: 21-34. In: Van Rensbergen R, Hillis RR, Maltman AJ, Morley CK Owen G, Moretti M, Alfaro P (eds) (2011) Subsurface sediment mobilisation. Recognising triggers for soft-sediment deformation: current understanding and future directions. Sedimentary Geology 235: 133-140.

Owen G, Moretti M, Alfaro P (2011) Recognising triggers for soft-sediment deformation: current understanding and future directions. Sedimentary Geology 235:133-140.

Perkins ME, Nash BP (2002) Explosive silicic volcanism of the Yellowstone hotspot: The ash fall tuff record. Geol Soc Am Bull 114:367-381

Perkins ME, Brown FH, Nash WP, Williams SK, McIntosh W (1998) Sequence, age, and source of silicic fallout tuffs in middle to late Miocene basins of the northern Basin and Range province. Geol Soc Am Bull 110:344-360

Pestana JM, Biscontin G, Nadim E, Andersen K (2000) Modeling cyclic behavior of lightly overconsolidated clays in simple shear. Soil Dyn Earthq Eng 19:501-519

Pierce KL, Morgan LA (1992) The track of the Yellowstone hot spot: volcanism, faulting, and uplift. Geol Soc Am Mem 179:1-54

Postma G (1984) Slumps and their deposits in fan delta front and slope. Geology 12:27-30

Shervais JW, Hanan BB (2008) Lithospheric topography, tilted plumes, and the track of the Snake River-Yellowstone hot spot. Tectonics 27:TC5004

Skilling IP, White JDL, McPhie J (2002) Peperite: a review of magma-sediment mingling. J Volcanol Geotherm Res 114: $1-17$

Tuffen H, Gilbert J, McGarvie D (2001) Products of an effusive subglacial rhyolite eruption: Bláhnúkur, Torfajökull, Iceland. Bull Volcanol 63:179-190

Waichel BL, de Lima EF, Sommer CA, Lubachesky R (2007) Peperite formed by lava flows over sediments: an example from the central Paraná Continental Flood Basalts, Brazil. J Volcanol Geotherm Res 159:343-354

Walker GW, MacLeod NS (compliers) (1991) Geologic map of Oregon. U.S. Geological Survey. Scale 1:500,000

Warner MM (1977) The Cenozoic of the Snake River Plain of Idaho. Rocky Mountain thrust belt geology and resources. In: 29th Annual Field Conference Guidebook: 313-326

White JDL, Houghton BF (2006) Primary volcaniclastic rocks. Geology 34:677-680

Woidt WD (1978) Finite element calculations applied to salt dome analysis. Tectonophysics 50:369-386

Wood SH, Clemens DM (2002) Geologic and tectonic history of the western Snake River Plain, Idaho and Oregon, Tectonic and Magmatic Evolution of the Snake River Plain Volcanic Province. Idaho Geol Surv Bull 30:69-103 